\title{
Conservation Biological Control: Effect of Bio Fertilizers and Bio Pesticides in Organic Ecological Engineering Field of Okra (Abelmoschus esculentus (L.) Moench)
}

\author{
E. Sree Latha*, S. Jesu Rajan, M. Narsi Reddy, \\ K. Sneha Madhuri and CH. Sreenivasa Rao
}

\begin{abstract}
PHM, NIPHM - National Institute of Plant Health Management, (An Organization of Department of Agriculture, Cooperation \& Farmers Welfare, Ministry of Agriculture, Govt. of India), Rajendranagar, Hyderabad - 500 030, Telangana, India
\end{abstract}

*Corresponding author

\section{A B S T R A C T}

\section{Keywords}

Okra, Conservation biological control, Organic farming, ecological engineering, Predators

Article Info

Accepted:

07 December 2018 Available Online: 10 January 2019
Okra (Abelmoschus esculentus) locally known as 'Bhendi' also known as lady's finger is a popular and most common annual vegetable crop in tropical and subtropical parts of the world. Several insect pests attack okra. Use of synthetic insecticides indiscriminately on okra causes environmental pollution and health hazards to human beings due to pesticide residues. Present day concern for pesticide residue free food has induced intense interest for organic farming. In organic farming use of chemical pesticides are not allowed to control pests, so alternate to it is use of biological control agents. Instead of producing and releasing bio control agents conservation biological control through ecological engineering is emerging as answer to the limited pest control options available in organic farming. In organic farming different bio fertilizers and bio pesticides usage is common practice to supply nutrients and manage pests. In the present study different bio fertilizer and bio pesticide treatments were tested with respect to Pest: Defender populations and it revealed that there was no significant difference between the treatments for pest defender dynamics. Ecological engineering can be promoted as low cost, sustainable strategy in all organic farming situations to manage insect pests.

\section{Introduction}

Okra (Abelmoschus esculentus (L.) Moench), known as bhendi /lady's finger belonging to family Malvaceae, is an important warm season vegetable crop having export potential as fresh vegetable. In India, okra is cultivated in an area of 0.507 million hectare with an annual production of 6.003 million tons (nhb.gov.in). Insect pests are major constraints in okra production; the important insect pests of okra are jassids (Amrasca biguttula biguttula), whitefly (Bemisia tabaci) and shoot and fruit borer (Earias vittella Fab.) The indiscriminate use of synthetic chemicals to manage these pests beyond tolerance limits has resulted in resistance, resurgence, secondary infestation, phyto-toxicity, toxicity 
to beneficial organisms and pesticide residues causing unwarranted health hazards to the consumers (Mandal et al., 2006).

Organic farming is emerging to satisfy the consumer needs of pesticide residue free food. FAO has defined "Organic agriculture is a unique production management system which promotes and enhances agro-ecosystem health, including biodiversity, biological cycles and soil biological activity, and this is accomplished by using on-farm agronomic, biological and mechanical methods in exclusion of all synthetic off-farm inputs". In organic farming management of insect pests and diseases is the major challenge as options to control these are limited when chemicals were excluded. Habitat manipulation through Ecological engineering i.e. managing insect pests using different types of plants which provide food and shelter to beneficial insects is emerging as new concept of conservation biological control.

Report from ifoam states that organic farming is a booming sector with 57.8 million hectares of organic agricultural land- the organic market grows to almost 90 billion US dollars. (www.ifoam.bio 2018)

Organic okra has huge demand in Indian and international market but okra is attacked by a number of phytophagous insects, diseases and mites during different growth stages, among them the spotted bollworms (Earias vittella Fab. and Earias insulana Boisd.) are the most important ones (Aziz et al., 2011). Maximum incidence of leafhopper and aphid was noticed in kharif crop, while whitefly and mite reached high in population in rabi crop. The plants nearing maturity showed more susceptible than other stages for these sucking pests (Anitha and Nandihalli, 2008). Natural enemies, parasitoids and predators are the main sources of reduction in the populations of noxious insect pests (Pfadt, 1980). Bio control agents and neem extracts have been reported eco-friendly options for management of insect pests of okra (Al-Eryan et al., 2001; Singh and Brar, 2004; Paulraj and Ignacimuthu, 2005).

\section{Materials and Methods}

NIPHM maintains ecological engineering organic field with poly culture and different categories of plants. During Kharif season paddy, maize, cotton, sun flower, bhendi, brinjal, sweet corn, chili, red gram, groundnut, tomato and different gourds and melons are major crops and during Rabi season paddy, cabbage, cauliflower, onion, radish, tomato, different gourds and melons and leafy vegetables were grown. Throughout the year sugarcane, papaya, different trees and flowering plants were maintained in the field. Small native nectar rich flowering plants were grown to attract beneficial insects and to provide food and shelter to parasitoids, repellent plants ocimum/basil were grown to repel gram pod borer and tobacco caterpillar; castor was maintained as trap crop for Spodoptera litura, marygold as attractant plant to Helicoverpa armigera throughout the year in field.

The experiments were laid in Randomized Block Design (RBD) with four replications and 6treatments. Entire field was with ecological engineering plants. The okra variety used for the trial was Arka Anamika. In kharif 2016 it was sown on 04/07/2016 and in Rabi 01/12/2016 and 24-9-2017. Plot size was six rows of $2 \mathrm{~m}$ long i.e. $3.6 \times 2 \mathrm{~m}$ planted at $45 \times 10 \mathrm{~cm}$ row-to-row and plant-to-plant spacing. Observations were taken from 4 WAS at weekly interval till the pest population was reduced to negligible number. Different biofertilizers and bio pesticides and their mixtures were tested to know their effect on the insect pest damage and beneficial insects. The details of the treatments were given in Table 1. 


\section{Data collection}

Data was collected on major insect pests and beneficial insects at weekly intervals. The data was recorded on the sucking insect pests which include jassid (Amrasca biguttula biguttula), whitefly (Bemisia tabaci), Aphid (Myzus persicae), thrips (Thrips tabaci) and mites (Tetranychus spp.), borers which includes shoot and fruit borer (Earias vittella Fab.), fruit borer (Helicoverpa armigera), leaf eating caterpillar (Spodoptera litura), and beneficial insects which includes lady bird beetles (Menochilus sp, Coccinella sp, Harmonia sp,), green lace wing (Chrysoperla carnea), different species of predatory spiders and pollinators.

\section{Aphid}

Five plants were selected and tagged. Leaves, flowers and fruits in selected plants were observed and the degree of infestation levels were recorded based on population index and categorized into grades as $0,1,2,3$ and 4 according to visual and inspection counts. The aphid index is shown in table 2 .

\section{Whitefly}

Five plants were randomly selected and tagged.

Three leaves from top, middle and lower portion of each plant of 5 tagged plants were observed for the presence of nymphs and adults of whitefly.

\section{Thrips and mites}

The observations were recorded on randomly selected five plants. The three leaves one each from top (young), middle (mature) and bottom (old) portions of tagged okra plants were examined with hand lenses both upper and lower portions of the leaves for adults and nymphs.

\section{Coccinellids, chrysoperla and spiders}

Five plants were randomly selected and tagged. Total number of grubs and adults of coccinellids, Chrysoperla and spiders of different species and other beneficial insects present on each plant were counted.

Pollinator bees were observed on entire plot, bees were collected for species identification and recorded.

Pheromone traps were placed for Helicoverpa armigera monitoring. Yellow sticky traps were set up for monitoring whitefly and blue sticky traps for thrips @ 4-5 traps/acre. Vermi wash and neem oil were sprayed on all treatments uniformly based on need. Maize is used as border crop followed by sunflower to attract and conserve predaceous true bugs. Bracon hebator and Bracon brevicornis were released in the field to control Lepidopteran larvae. Attractant plants sunflower, mary gold, chrysanthemum, anise, mustard, and cowpea were raised for braconid wasps.

\section{Statistical analysis}

All the parameters were analysed using one way ANOVA in randomized block design.

\section{Results and Discussion}

Studies on the incidence of predator and pest interactions in okra during the three seasons of two consecutive years 2016 \& 2017 Kharif and Rabi have been done at NIPHM field Rajendranagar. Remarkable incidence of pest started from 4 weeks after sowing in all the seasons. Leaf hoppers were observed initially, followed by aphids, whiteflies, thrips and mites. Natural enemies observed in the same field were cocinellids and the spiders. In Kharif-2016, the population of all the pests were recorded treatment wise and as there were no significant differences between the 
treatments either in pest or predator population,mean of these observations were represented graphically given in Figure 1, the leafhopper population is recorded first amongst all pests with average of $0.11 / 3$ leaves in the 4WAS and gradually increased to $3.83 / 3$ leaves during the $10^{\text {th }}$ WAS, later again the population started declining and reached 0.25 leafhoppers/ 3 leaves in the $14^{\text {th }}$ WAS. Aphids and whiteflies population were observed to be peak during the $10^{\text {th }}$ WAS 0.39 aphids/ 3 leaves and 2.55 a whiteflies / 3 leaves respectively, later decreased to 0.03 aphids/ 3 leaves and 0.20 whiteflies / 3 leaves during $14^{\text {th }}$ WAS. Whereas the cocinellid population found to be increasing from $4 \mathrm{WAS}$ 0.02 to $10^{\text {th }}$ WAS 0.08 and later on decreased to 0.03 (Table 1).

In summer-2017, the population of all the pests were recorded treatment wise and as there were no significant differences between the treatments either in pest or predator population, mean of these observations were represented graphically given in Figure 2, the leafhopper population is recorded first amongst all pests with average of $0.49 / 3$ leaves in the 4WAS and gradually increased to $3.81 / 3$ leaves during the $10^{\text {th }}$ WAS, later again the population started declining and reached 0.90 in the $14^{\text {th }}$ WAS. Aphids and whiteflies populations were observed from 6 WAS 0.03 and 0.62 respectively, 0.27 and 2.00 during 8 WAS, 0.35 and 2.63 during the $10^{\text {th }}$ WAS. Whereas the cocinellid population found to be increasing from 4WAS 0.04 to $8^{\text {th }}$ WAS 0.08 and later on decreased 0.06 , the spiders were also reported during the 6WAS and 8 WAS with 0.05 population (Table 2 ).

In Kharif-2017, the population of all the pests were recorded treatment wise and as there were no significant differences between the treatments either in pest or predator population, mean of these observations were represented graphically given in Figure 3, the leafhopper population is recorded first amongst all pests with average of 2.00/ 3 leaves in the 4WAS and gradually started declining and reached 0.22 in the $14^{\text {th }}$ WAS. Aphids and whiteflies population were observed from 4 WAS 0.19 and 1.54 respectively, whitefly population gradually decreased by 0.66 in $10^{\text {th }}$ WAS and 0.03 in $12^{\text {th }}$ WAS. Thrips population was also observed 1.07 in $10^{\text {th }}$ WAS and 0.47 in $12^{\text {th }}$ WAS. Whereas the cocinellid population found to be 0.14 during 4WAS, 0.07, 0.03, $0.03,0.03$ and 0.04 respectively in $6,8,10,12$ and 14 WAS respectively, the spiders were also reported during the 4WAS and 12 WAS with 0.10 and 0.01 population.

The results from the studies on the incidence of predator and pest interactions in okra during the three seasons of two consecutive years 2016 \& 2017 Kharif and Rabi had revealed the remarkable incidence of pest started from 4 weeks after sowing in all the seasons. Leaf hoppers were observed initially, followed by aphids, whiteflies, thrips and mites. Natural enemies observed in the same field were cocinellids and the spiders.

During the Kharif 2016 there was no significant difference between the treatments either in pest or predator population. Mean of these observations shown that thee pest population of all the species below ETL level. The leafhopper incidence started in $30^{\text {th }}$ standard week with 0.11 leafhoppers/ 3leaves of plant, aphids population observed from $34^{\text {th }}$ standard week with an average of 0.35 aphids/ 3 leaves of plant, whitefly population observed from $36^{\text {th }}$ standard week with an average of 2.55 whiteflies/ 3 leaves of plant and the natural enemy population was found all over the season i.e., from sowing to end of the crop. These results are similar with the findings of (8) Kabre 2016 who reported the peak incidence of whiteflies and aphids during the third week of September. Also in accordance with the findings of Jesu Rajan et al., (2018) who reported the coccinellid 
feeding behaviour over aphids. In summer crop (2016-2017), the population of all the pests were recorded treatment wise and as there were no significant differences between the treatments either in pest or predator population, mean of these observations showed that the pest population of all the pest species below ETL level.

The leafhopper population found to be started its incidence in $52^{\text {nd }}$ standard week with 0.49 leafhoppers/ 3leaves, aphids population observed from $2^{\text {nd }}$ standard week with an average of 0.35 aphids/ 3 leaves, whitefly population observed from $36^{\text {th }}$ standard week with an average of 2.55 whiteflies/ 3 leaves and the natural enemy population was found throught the season i.e., from sowing to end of the crop these results are similar with the findings of (Anurag potai 2018), who reported the peak activity of jassids and aphids during $39^{\text {th }}$ standard week. Natural enemies population like ladybird beetles and spiders presence were also noticed during these periods.

\section{Incidence of insect pest of okra}

Indiscriminate use of chemical fertilizers and pesticides drastically reduced biodiversity in agriculture ecosystem. Especially the decline in beneficial insects like parasitoid, predator and pollinator population leading to the problems of pest resurgence and ecosystem services like pollination. Ecological engineering promotes diversification of cropping system which provides food and shelter to natural enemies, to reduce pest pressure and to enhance pollination (Anil Meena 2017). Important pests of Bhendi are Shoot and fruit borer: Earias vitella (Fabricius) (Lepidoptera Noctuidae) $E$ insulana (Boisduval) (Lepidoptera Noctuidae), Gram pod borer: Helicoverpa armigera (Hübner) (Lepidoptera Noctuidae), Jassids: Amrasca biguttula biguttula Ishida (Hemiptera Cicadellidae), Aphids: Aphis gossypii Glover (Hemiptera Aphididae), Whitefly: Bemisia tabaci (Gennadius) (Hemiptera Aleyrodidae) and Red spider mite Tetranychus spp. (Acarina

Tetranychida.

Table.1 Details treatments used to conduct experiment

\begin{tabular}{|c|c|c|}
\hline Sl.No & $\begin{array}{l}\text { Treatment } \\
\text { Number }\end{array}$ & Details of the treatment \\
\hline 1 & $\mathrm{~T} 1$ & Neem cake+ Vemicompost + Vermiwash spray \\
\hline 2 & $\mathrm{~T} 2$ & Soil treatment with Biofertilizer (Mychorryza) \\
\hline 3 & T3 & $\begin{array}{l}\text { Soil treatment with Bio pesticides (Trichoderma harzianum }+ \\
\text { Pseudomonas fluroscence) }\end{array}$ \\
\hline 4 & T4 & $\begin{array}{l}\text { Biopesticides (Trichoderma harzianum) + Pseudomonas fluroscence)+ } \\
\text { Biofertilizer (Mychorryza )+ PSB (Phosphate Solubilizing Bacteria) + } \\
\text { KSB (Potassium Solubilizing Bacteria) + ZSB (Zinc Solubilizing } \\
\text { Bacteria) }\end{array}$ \\
\hline 5 & T5 & $\begin{array}{l}\text { Soil treatment with neem cake }+ \text { Vemicompost }+ \text { biopesticides (Tri. + } \\
\text { Pseudo.) }+ \text { Biofertilizer (Mychorryza )+ PSB (Phosphate Solubilizing } \\
\text { Bacteria) }+ \text { KSB (Potassium Solubilizing Bacteria) + ZSB (Zinc } \\
\text { Solubilizing Bacteria) }\end{array}$ \\
\hline 6 & T6 & Control \\
\hline
\end{tabular}


Table.2 Aphid infestation index

\begin{tabular}{|l|l|}
\hline Grade & Aphid index \\
\hline 0 & No aphid population on plant \\
\hline 1 & $\begin{array}{l}\text { One or two aphids observed on plant but colony was not formed } \\
\text { damage symptoms seen }\end{array}$ \\
\hline 2 & $\begin{array}{l}\text { Big colony of aphids was observed on plant and aphids can be counted and } \\
\text { damage symptoms seen }\end{array}$ \\
\hline 4 & $\begin{array}{l}\text { Big colony of aphids were observed on plant and aphids could not be counted } \\
\text { because of huge number and severe damage symptoms seen and plant withered }\end{array}$ \\
\hline
\end{tabular}

Fig.1 Predator and pest interactions in okra at Niphm field, Rajendranagar (DOS: 04-07-2016)

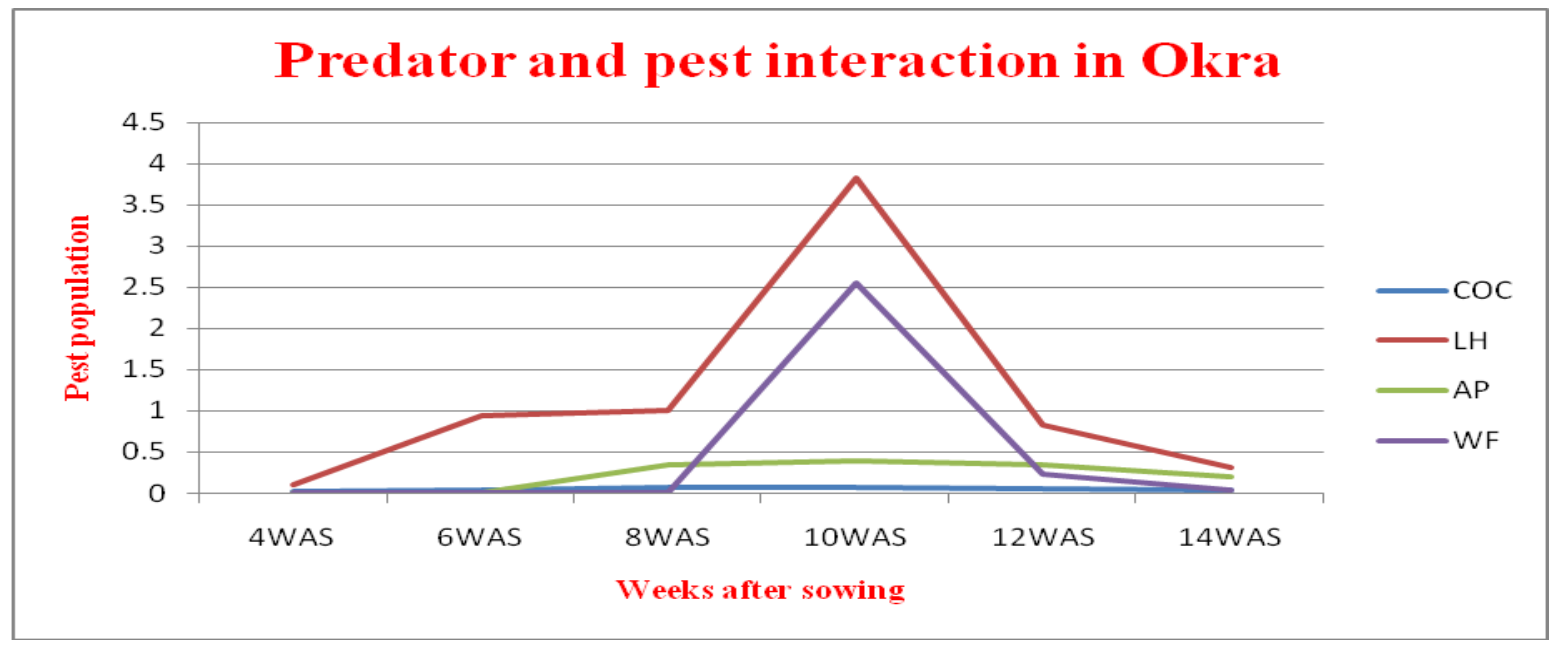

LH-Leaf Hoppers, WF- Whitefly, AP-Aphids, COC-Coccinellids, SP-Spiders

Fig.2 Predator and pest interactions in okra at Niphm field, Rajendranagar (DOS: 01-12-2016)

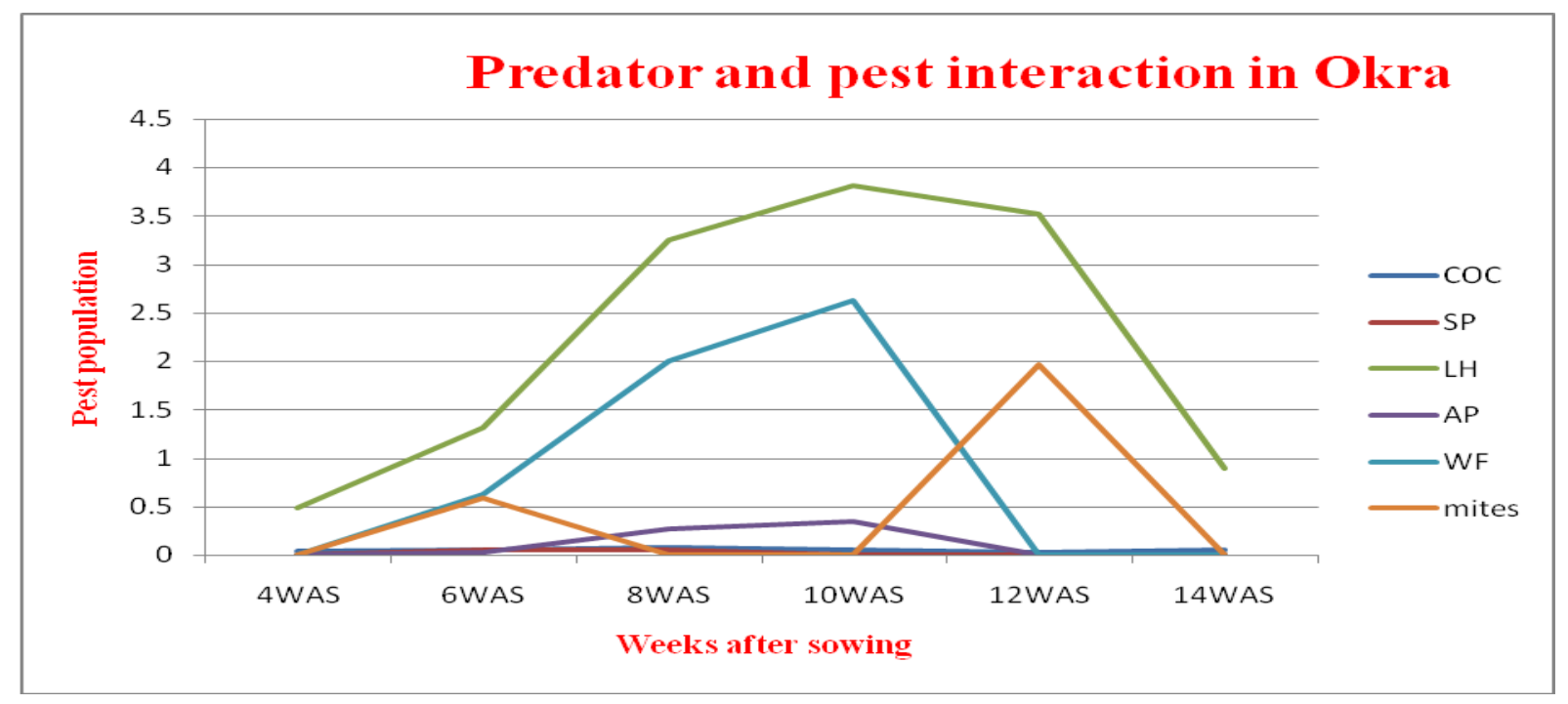


Fig.3 Predator and pest interactions in okra at Niphm field, Rajendranagar (DOS: 24-09-2017)

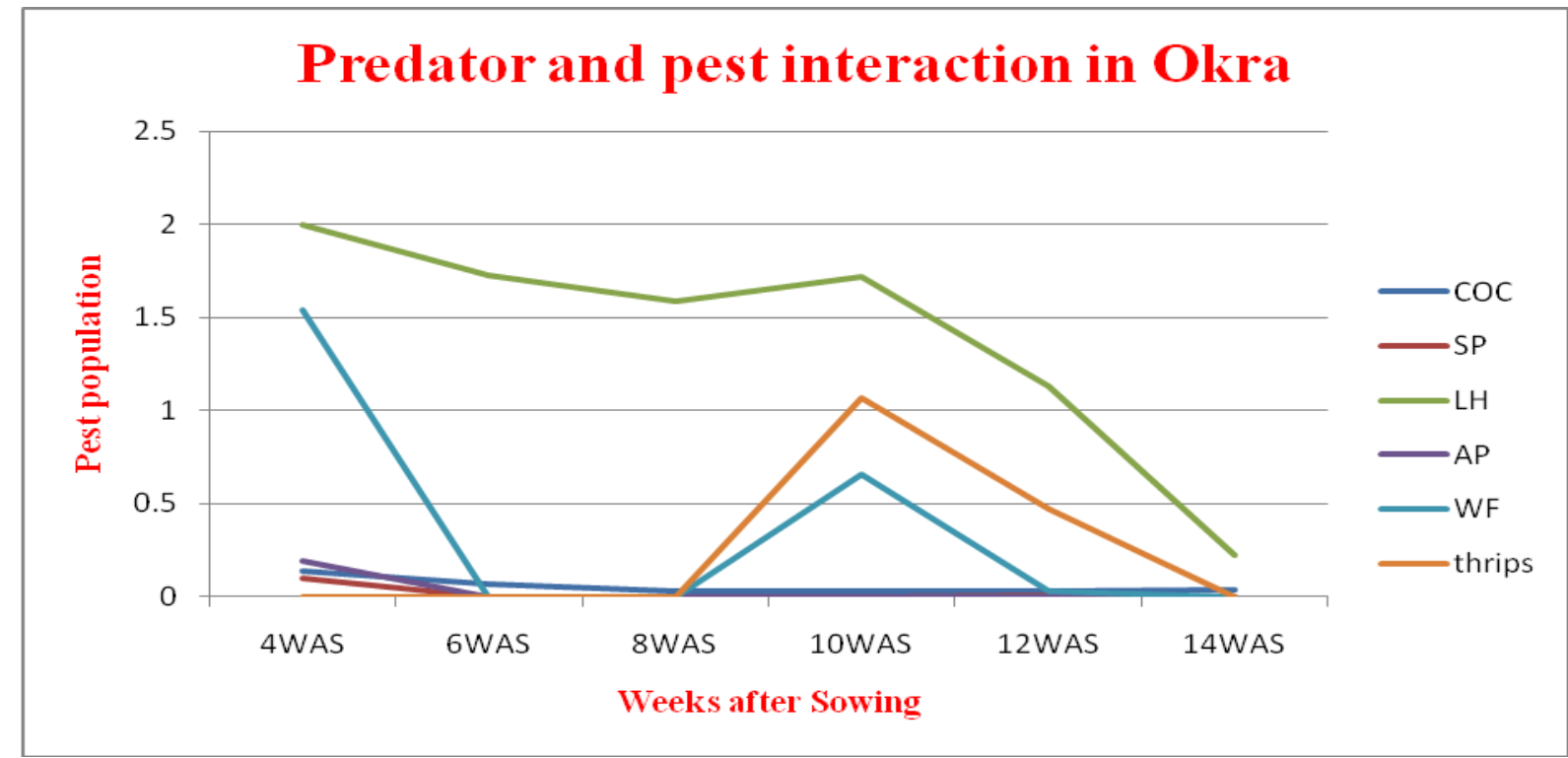

In ecological engineering filed major pests like fruit borer and gram pod borer were not recorded. This indicates the ecological engineering controlling rate on the pest population. (http://niphm.gov.in/IPM Packages/Okra.pdf)

Release of the predator, Chrysoperla carnea $(25,000 \quad$ larvae/ha/release $) \quad+$ application of Econeem $0.3 \%$ (0.5 1/ha) for three times at 15 days interval starting from 45 days after sowing was found to be effective in reducing the population of sucking pests as well as the fruit borers (Praveen and Dhandapani, 2001).

The study conducted on organic farming in vegetable crops at IIVR, Varanasi, revealed that the productivity of vegetables crop in organic farming was less in initial years but the yields increased progressively under organic farming equating the yields under conventional inorganic farming in 4-5 years, Organic produce contains more vitamins, minerals, enzymes, trace elements and even cancer fighting antioxidants than conventionally grown food (Singh et al, 2016; Bhattacharya and Chakraborty, 2005).
The quality, taste and flavour improves in organically produced vegetables mainly through increased dry matter, vitamin C, protein content and quality, decreased free nitrates in vegetables, decreases storage losses and disease. Research work also showed that organically grown vegetables have higher vitamin $\mathrm{C}$, total carotenoids, higher mineral levels and higher phytonutrients, which can be effective against cancer (Worthington 1998).

\section{References}

Anitha, K. R. and Nandihalli, B. S. 2008. Utilization of botanicals and mycopathogens in the management of sucking pests of okra. Karnataka Journal of Agriculture Sciences, 21(2): 231-233.

Anil Meena, Monika Meena, Rakesh Kumar and Braj Mohan Meena. 2017 Farmscaping: An ecological approach to insect pest management in agroecosystem. Journal of Entomology and Zoology Studies; 5(3): 598-603

Anurag Potai and Gajendra Chandrakar 2018. Studies on the Seasonal Incidence of Major Insect Pests and its Natural 
Enemies on Okra and Their Correlation with Weather Parameters. Int.J.Curr.Microbiol.App.Sci Special Issue-6: 204-210.

Al-Eryan, M. A. S., Zaitoon, A. A. and Rezk, H.A. 2001. The use of Coccinella 11punctata (Coleoptera: Coccinellidae) against Aphis gossypii (Homoptera: Aphididae) on okra plant. Alexand. $J$. agric Res., 46: 107-114.

Aziz, M.A., Hasan, M. and Ali, A.2011. Impact of abiotic factors on incidence of fruit and shoot damage of spotted bollworms Earias spp. on okra (Abelmoschus esculentus L.). Pakistan J. Zool., 43: 863-868.

Bhattacharaya P and Chakraborty G. (2005). Current status of organic farming in India and other countries. Indian $J$. Fert. 1(9): 111-123.

http://niphm.gov.in/IPMPackages/Okra.pdf http://nhb.gov.in/statistics/State_Level/area_p rod20161718.pdf

https://www.ifoam.bio/en/news/2018/02/14/b ooming-organic-sector-578-millionhectares-organic-agricultural-landorganic-market

Jesu Rajan S, Sree Latha E, Vijaya Raghavendra R and CH Sreenivasa Rao 2018 Biology and feeding potential of Coccinella transversalis (Fab.) on cabbage aphid, Brevicoryne brassicae (Linn.). Journal of Entomology and Zoology Studies; 6(6): 51-56.

G. B. Kabre, S. S. Khating, And A.A. Dhainje 2016 Seasonal incidence of sucking pests of okra along with natural enemies in Khandesh region of Maharashtra
Asian Journal Of Bio Science; 11(2) 269-272.

Mandal, S.K., Sah, S..B. and. Gupta S.C. 2006. Efficacy and economics of biopesticide and insecticide combinations against okra pests. International Journal of Agricultural Sciences 2(2): 377-380.

Paulraj, M.G. and Ignacimuthu, T. 2005. Predatory insect fauna in mixed cropping agro ecosystems in Northeastern Tamil Nadu. Insect Environ., 11: 79- 82.

Pfadt, R.E., 1980. Fundamentals of applied entomology. Macmillan Company, New York, pp. 99-104, 24-126.

P. M. Praveen \& N. Dhandapani 2001 EcoFriendly Management of major pests of Okra(Abelmoschus esculentus (L.) Moench) Journal of vegetable crop production;7(2)3-12.

Singh, J. and Brar, K.S., 2004. Mass production and biological control potential of coccinellids in India. In: Indian insect predators in biological control (ed. K. Sahayaraj) Daya Publishing House, Delhi, India, pp. 204260.

Singh SK, Yadava RB, Chaurasia SNS, Prasad RN, Singh Raghwendra, Chaukhande Paresh and Singh B. (2016). Producing organic vegetables for better health. Indian Hort. 61(1):5-8.

Worthington V, 1998, 'Effect of agricultural methods on nutritional quality: a comparison of organic with conventional crops', Alternative Therapies Health Med 4(1), p 58-69

\section{How to cite this article:}

Sree Latha, E., S. Jesu Rajan, M. Narsi Reddy, K. Sneha Madhuri and Sreenivasa Rao, CH. 2019. Conservation Biological Control: Effect of Bio Fertilizers and Bio Pesticides in Organic Ecological Engineering Field of Okra (Abelmoschus esculentus (L.) Moench). Int.J.Curr.Microbiol.App.Sci. 8(01): 548-555. doi: https://doi.org/10.20546/ijcmas.2019.801.061 